Louisiana State University

LSU Digital Commons

Faculty Publications

Department of Chemistry

$1-1-2019$

\title{
Fluorescence-Based Ratiometric Nanosensor for Selective Imaging of Cancer Cells
}

Isiah M. Warner

Louisiana State Univ, Dept Chem, iwarner@lsu.edu

Kelsey E. McNeel

Louisiana State Univ, Dept Chem

Noureen Siraj

Louisiana State Univ, Dept Chem

Nimisha Bhattarai

Louisiana State Univ, Dept Chem

Follow this and additional works at: https://digitalcommons.Isu.edu/chemistry_pubs

Part of the Chemistry Commons

\section{Recommended Citation}

Warner, Isiah M.; McNeel, Kelsey E.; Siraj, Noureen; and Bhattarai, Nimisha, "Fluorescence-Based Ratiometric Nanosensor for Selective Imaging of Cancer Cells" (2019). Faculty Publications. 27.

https://digitalcommons.Isu.edu/chemistry_pubs/27

This Article is brought to you for free and open access by the Department of Chemistry at LSU Digital Commons. It has been accepted for inclusion in Faculty Publications by an authorized administrator of LSU Digital Commons. For more information, please contact gcoste1@lsu.edu. 


\title{
Fluorescence-Based Ratiometric Nanosensor for Selective Imaging of Cancer Cells
}

\author{
Kelsey E. McNeel, ${ }^{\dagger}$ Noureen Siraj, ${ }^{\dagger,}$ Nimisha Bhattarai, ${ }^{\dagger}$ and Isiah M. Warner* ${ }^{* \dagger}$ \\ ${ }^{\dagger}$ Department of Chemistry, Louisiana State University, Baton Rouge, Louisiana 70803, United States \\ ${ }^{\ddagger}$ Department of Chemistry, University of Arkansas at Little Rock, Little Rock, Arkansas 72204, United States
}

\section{Supporting Information}

ABSTRACT: Herein, we report the synthesis and characterization of a nanosensor developed from a group of uniform materials based on organic salts (GUMBOS). This sensor is composed of three ionic species, namely, fluorescein, rhodamine $\mathrm{B}$, and tetradecyltrihexyl phosphonium $\left(\mathrm{P}_{66614}\right)$ ions. Nanoparticles prepared from this three-component GUMBOS, termed nanoGUMBOS, exhibited increased fluorescence at two wavelengths with increases in $\mathrm{pH}$ values. The ratio of fluorescence emission corresponding to FL and RhB components of these nanoGUMBOS also changed with $\mathrm{pH}$, allowing ratiometric analysis of $\mathrm{pH}$ through fluorescence measurements. Peak

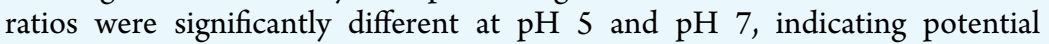
applications of this nanomaterial as a cancer diagnostic tool. In this regard, in vitro fluorescence microscopy was employed to image cancerous and normal breast cells incubated with nanoGUMBOS. Fluorescence imaging of cancer cells showed higher uptake of these nanoGUMBOS and more pervasive fluorescence intensity in comparison with normal cells. Thus, the synthesized novel nanomaterial shows a great potential for rapid visual imaging of cancer cells.

\section{INTRODUCTION}

Extracellular and intracellular sensing of $\mathrm{pH}$ are important tasks because of fluctuation of $\mathrm{pH}$ values with conditions such as cancer and bacterial infections. Both healthy and cancerous cells tightly regulate $\mathrm{pH}$ within the cell (intracellular $\mathrm{pH}$ ) at typical values between 7.0 and 7.4. ${ }^{1}$ Healthy extracellular $\mathrm{pH}$ values are generally between 5.5 and 7.4. However, extracellular $\mathrm{pH}$ in healthy individuals can be lowered because of cancer, renal failure, acidosis, chronic obstructive pulmonary disease, and many other adverse conditions. ${ }^{2,3}$ Therefore, an extracellular $\mathrm{pH}$ sensor would be an effective diagnostic tool for abnormal $\mathrm{pH}$ value conditions that are traditionally acidic. Such $\mathrm{pH}$ sensors are also of great importance to agricultural, ${ }^{4}$ environmental, ${ }^{5}$ biological, ${ }^{6}$ and food manufacturing applications. For instance, the dairy industry requires $\mathrm{pH}$ sensing for several processes such as checking the freshness of milk, bacterial conversion of lactose to lactic acid in yogurt, cheese production, and so on. ${ }^{7}$ The importance of $\mathrm{pH}$ sensing has led to development of many types of sensors such as potentiometric sensors, ${ }^{8}$ electrolyte-insulator-semiconductor sensors, ${ }^{9}$ and fluorescence sensors. Fluorescence $\mathrm{pH}$ sensors are of particular interest owing to the high sensitivity, selectivity, and speed inherent to fluorescence measurements. ${ }^{10,11}$ Moreover, nanomaterials can be used to enhance many such $\mathrm{pH}$ sensors by facilitating the manipulation of solubility, fluorescence intensity, and combinations of multiple beneficial components. ${ }^{12}$ Furthermore, nanoscale $\mathrm{pH}$ sensors are important for intracellular $\mathrm{pH}$ sensing because they can be used with minimal invasion and can be relatively easily synthesized using size-controlled processes for optimum cellular uptake. ${ }^{13}$

Common designs of nanoscale fluorescent $\mathrm{pH}$ sensors include the incorporation of fluorescent moieties into various nanoparticle matrices prepared from materials such as polymer $^{14,15}$ and silica. ${ }^{16,17} \mathrm{~A}$ microemulsion approach has also been applied for the formation of $\mathrm{pH}$-sensitive fluorescent nanoparticles. ${ }^{18}$ Regardless of the method used to synthesize nanoparticles, several properties are required from an ideal nanoparticle-based $\mathrm{pH}$ sensor depending on the application. As an example, for cellular $\mathrm{pH}$ sensors, one of the important properties is that the range of $\mathrm{pH}$ sensing ability should encompass $\mathrm{pH}$ values relevant to the biological systems of interest. ${ }^{19}$ Additionally, sensing should not be inhibited by components within the cell, for example, calcium and sodium ions. ${ }^{20}$ Typical fluorescence-based $\mathrm{pH}$ sensing techniques are impacted by variables such as source intensity, photobleaching, and path length of the measurement. These variables require calibration of sensing systems for accurate measurements. ${ }^{21}$ The need for calibration is an especially large deficiency for cellular studies because of variations in path length in different parts of the cell and between different cells. ${ }^{22}$

Received: October 11, 2018

Accepted: January 8, 2019

Published: January 23, 2019 
Fluorophores with multiple independent emission peaks can be used to overcome calibration needs. For example, ratiometric responses (i.e., the emission intensity ratio between two peaks) can be achieved using a single fluorophore with varied acidic and basic emission, ${ }^{23}$ two fluorophores that exhibit $\mathrm{pH}$-dependent Fürster resonance energy transfer (FRET) $){ }^{24}$ or one fluorophore with $\mathrm{pH}$-dependent emission and one fluorophore with $\mathrm{pH}$-independent emission. ${ }^{25}$ Thus, it has been established that ratiometric measurements provide an intrinsic calibration that is relatively inert to sensitivities of typical cellular fluorescent measurements.

Despite the many and various needs for $\mathrm{pH}$ sensors, there is still a significant need for inexpensive $\mathrm{pH}$ sensors that employ simple synthesis with high yields. ${ }^{26}$ In this regard, a group of uniform materials based on organic salts (GUMBOS) are solid phase ionic materials renowned for their tunability and broad applicability and have demonstrated capabilities as $\mathrm{pH}$ sensors. $^{27,28}$ Other potential GUMBOS applications vary from photosensitizers in solar cells, ${ }^{29}$ use in OLEDs, ${ }^{30}$ sensing applications, ${ }^{31,32}$ cancer treatment, ${ }^{33}$ and beyond. In the study reported herein, we demonstrate a three-component, nanoscale, fluorescent GUMBOS as a $\mathrm{pH}$ sensor probe composed of fluorescein (FL), rhodamine $\mathrm{B}(\mathrm{RhB})$, and tetradecyltrihexyl phosphonium ions $\left(\mathrm{P}_{66614}\right)$, which is scripted as $\left[\mathrm{P}_{66614}\right]$ $[\mathrm{RhB}][\mathrm{FL}]$. Cationic $\mathrm{P}_{66614}$ was chosen for its significant hydrophobicity, a property necessary for nanoparticle formation from insoluble material in aqueous media. Anionic FL and cationic $\mathrm{RhB}$ were selected for their spectral overlap essential for FRET measurement, where FL serves as the donor and $\mathrm{RhB}$ as the acceptor. It is well-established that the intermolecular distance between a donor and an acceptor is critical and should be less than $10 \mathrm{~nm}$ for efficient FRET. ${ }^{34}$ Incorporation of these ions into a single GUMBOS reduces the distance between donor and acceptor and thus allows effective FRET measurement. Effective FRET should result in two fluorescence emission peaks of $\left[\mathrm{P}_{66614}\right][\mathrm{RhB}][\mathrm{FL}]$. The ratio of intensities between these peaks is expected to vary with $\mathrm{pH}$. Therefore, ratiometric analysis can be performed similar to the process employed by Cong, et al. ${ }^{35}$ Thus, it is expected that $\left[\mathrm{P}_{66614}\right][\mathrm{RhB}][\mathrm{FL}]$ nanoparticles should yield an intrinsically calibrated fluorescence method for the distinction of $\mathrm{pH}$ values between 4 and 7. This three-component nanoGUMBOS was also found to be preferentially taken up by cancer cells, providing a rapid visual detection method using $\left[\mathrm{P}_{66614}\right]$ $[\mathrm{RhB}][\mathrm{FL}]$ nanoGUMBOS. Such preferential GUMBOS intake has been previously reported by our group. ${ }^{33}$ Herein, we report on detailed characterization, analyses, and application of this compound for use as a $\mathrm{pH}$ sensor and cancer imaging agent.

\section{RESULTS AND DISCUSSION}

\subsection{Spectroscopic Characterization of Synthesized} GUMBOS. In addition to nuclear magnetic resonance (NMR) confirmation and Supporting Information (Figures S1 and S2), GUMBOS synthesis is supported by comparing UV-vis absorbance and fluorescence spectra of the parent dyes and GUMBOS. The absorbance spectrum of $\left[\mathrm{P}_{66614}\right][\mathrm{RhB}][\mathrm{FL}]$ GUMBOS retained all spectral features of parent dyes FL and $\mathrm{RhB}$ (Figure 1). However, the absorbance of FL at $505 \mathrm{~nm}$ is significantly reduced in $\left[\mathrm{P}_{66614}\right][\mathrm{RhB}][\mathrm{FL}]$ compared to native $\mathrm{FL}$, and shoulders in the absorption spectrum of $\left[\mathrm{P}_{66614}\right]$ $[\mathrm{RhB}][\mathrm{FL}]$ at approximately 430 and $450 \mathrm{~nm}$ were present. Absorbance of $\left[\mathrm{P}_{66614}\right][\mathrm{RhB}][\mathrm{FL}]$ between 400 and $520 \mathrm{~nm}$

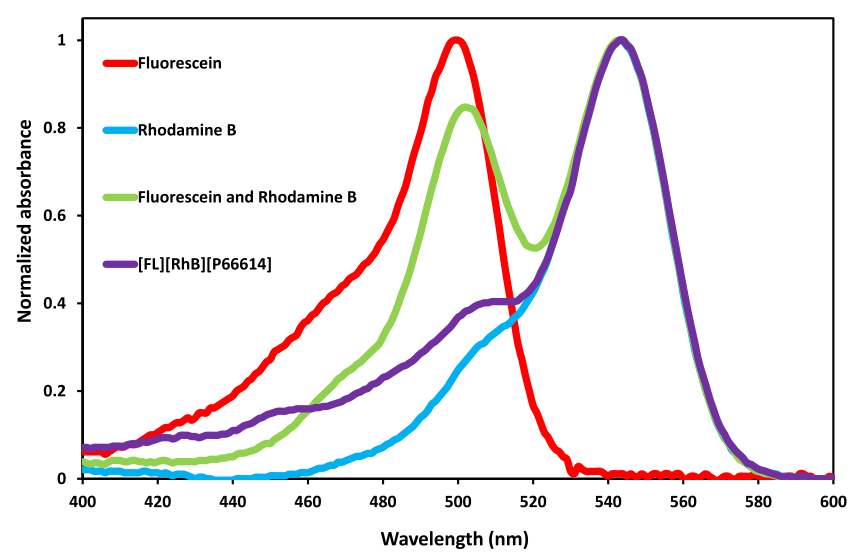

Figure 1. Normalized UV-vis absorbance spectra of ethanolic solutions: $10 \mu \mathrm{M}$ of parent dye $\mathrm{RhB}, 10 \mu \mathrm{M}$ of the parent dye $\mathrm{FL}$, a mixture containing $10 \mu \mathrm{M}$ each of $\mathrm{RhB}$ and $\mathrm{FL}$, and $10 \mu \mathrm{M}$ GUMBOS $\left[\mathrm{P}_{66614}\right][\mathrm{RhB}][\mathrm{FL}]$.

corresponds to the known absorbance spectrum of mixed protolytic forms of FL (viz. cationic, neutral, monoanionic, and dianionic).$^{36}$ Reduced absorbance at $505 \mathrm{~nm}$ further supports the inclusion of multiple FL species (i.e., protolytic forms) exist within the three-component GUMBOS. Absorbance of parent dye $\mathrm{RhB}$ was not significantly impacted by incorporation into $\left[\mathrm{P}_{66614}\right][\mathrm{RhB}][\mathrm{FL}]$. Examination of stability of $\mathrm{RhB}$ absorbance in $\left[\mathrm{P}_{66614}\right][\mathrm{RhB}][\mathrm{FL}]$ indicates that GUMBOS formation is not likely to inhibit FRET acceptance.

Fluorescence spectroscopy was used to further verify the synthesis of $\left[\mathrm{P}_{66614}\right][\mathrm{RhB}][\mathrm{FL}]$ GUMBOS (Figure 2).

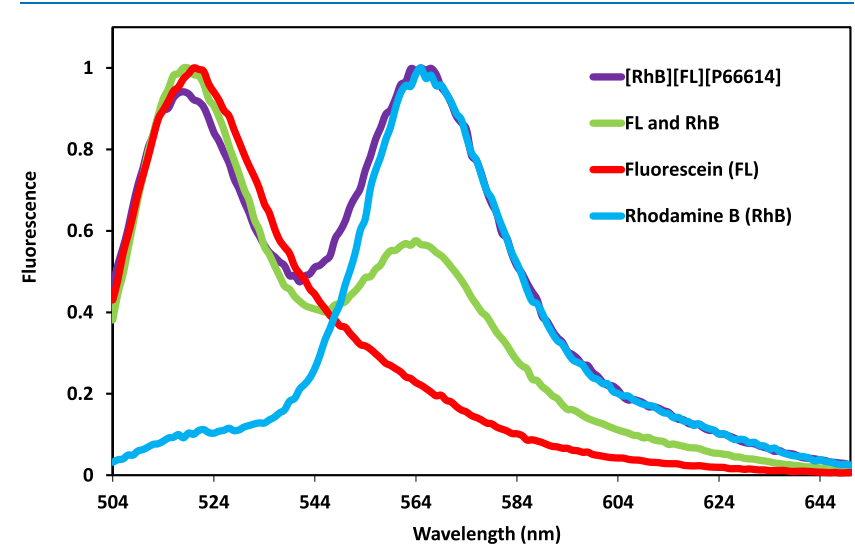

Figure 2. Normalized fluorescence spectra of $10 \mu \mathrm{M}$ ethanolic solutions of $\mathrm{FL}, \mathrm{RhB}, \mathrm{FL}$ and $\mathrm{RhB}$, and $\left[\mathrm{P}_{66614}\right][\mathrm{RhB}][\mathrm{FL}]$ GUMBOS. $\lambda_{\mathrm{ex}}=495 \mathrm{~nm}$.

Fluorescence emission of individual parent dyes was somewhat affected as a result of the presence of the other fluorophore in solution. Thus, a solution with $10 \mu \mathrm{M}$ each FL and RhB showed fluorescence emission in which the FL peak intensity was slightly quenched, whereas $\mathrm{RhB}$ emission was enhanced, indicating a slight occurrence of FRET. Fluorescence emission of the mixture did not exhibit a peak shift as compared to separate fluorophore solutions of $10 \mu \mathrm{M}$ each. When two dyes were incorporated into a GUMBOS with $\mathrm{P}_{66614}$, the fluorescence emission peak corresponding to FL was reduced significantly, much more so than in free solution. This reduction in emission is likely due, in part, to reduced absorbance of $\left[\mathrm{P}_{66614}\right][\mathrm{RhB}][\mathrm{FL}]$ GUMBOS at the excitation 
wavelength. Furthermore, emission of $\left[\mathrm{P}_{66614}\right][\mathrm{RhB}][\mathrm{FL}]$ at $565 \mathrm{~nm}$ (band corresponding to $\mathrm{RhB}$ ) was more intense than that at $520 \mathrm{~nm}$ (band corresponding to FL). The change in intensity ratios suggests that, as expected, the formation of GUMBOS reduced the distance between FL and RhB sufficiently to achieve significant FRET.

2.2. Spectral Overlap Integral and Forster Distance of Fluorescein and Rhodamine B. In addition to limited spatial distance, another condition for FRET to occur is the sufficient spectral overlap between the emission spectrum of donor and the absorbance spectrum of acceptor. A high spectral overlap indicates high probability of FRET. In that regard, calculation of the spectral overlap integral was performed using the following equation

$$
J(\lambda)=\frac{\int_{0}^{\infty} \varepsilon(\lambda) f(\lambda) \lambda^{4} \mathrm{~d} \lambda}{\int_{0}^{\infty} f(\lambda) \mathrm{d} \lambda}
$$

where $\varepsilon$ is the molar extinction coefficient of acceptor species $\left(\mathrm{cm}^{-1} \mathrm{M}^{-1}\right), f(\lambda)$ is the normalized emission intensity of donor, and $\lambda$ is the wavelength. We note that FL (donor) and $\mathrm{RhB}$ (acceptor) were chosen because they have a significant and appropriate spectral overlap, calculated to be $J(\lambda)=4.88 \times$ $10^{15} \mathrm{M}^{-1} \mathrm{~cm}^{-1} \mathrm{~nm}^{4}$ under our experimental conditions (Figure 3).

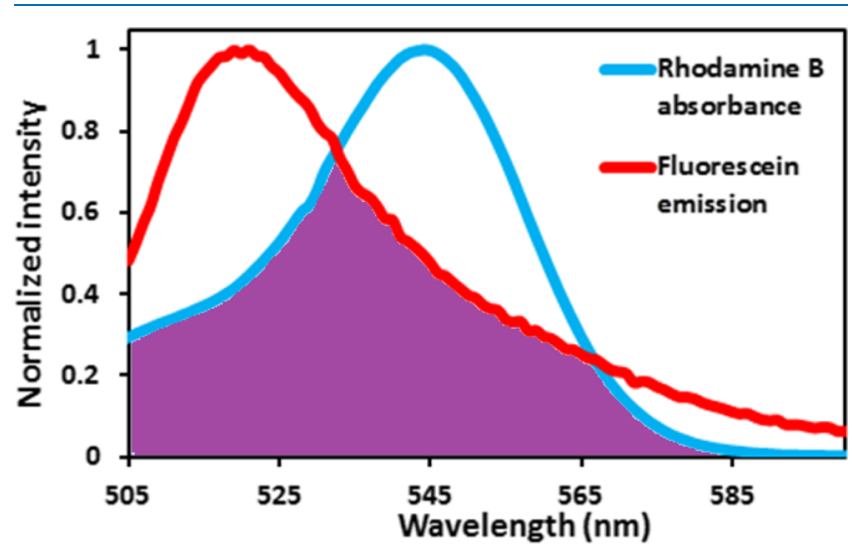

Figure 3. Spectral overlap of normalized FL emission and $\mathrm{RhB}$ absorbance. Shaded area indicates spectral overlap $[J(\lambda)]$.

The critical FRET transfer distance, $R_{0}$, was calculated using the equation

$$
R_{0}=0.2108\left(\kappa^{2} \Phi_{0} n^{-4} J\right)^{1 / 6}
$$

where $\kappa^{2}$ is the orientation factor, $\Phi_{0}$ is the quantum yield of the donor molecule, $n$ is the refractive index of the medium, and $J$ is the previously discussed spectral overlap. $R_{0}$ was calculated to be $61.48 \AA$ under our experimental conditions.

2.3. Energy-Transfer Efficiency of $[\mathrm{RhB}][\mathrm{FL}]\left[\mathrm{P}_{66614}\right]$ GUMBOS. Energy-transfer efficiency $(E)$ was calculated using the following equation

$$
E=\left(1-\frac{F_{\mathrm{da}}}{F_{\mathrm{d}}}\right) \times 100 \%
$$

where $F_{\mathrm{da}}$ is the fluorescence intensity of a donor in the presence of an acceptor and $F_{\mathrm{d}}$ is the fluorescence intensity of a donor in absence of an acceptor. $E$ quantifies the percentage of energy emitted by a donor that is subsequently absorbed by an acceptor. A higher value of $E$ indicates a more efficient FRET pair. For calculation of $E$ relevant to this study, ethanolic FL was used for $F_{d}$ determination, and $\left[\mathrm{P}_{66614}\right][\mathrm{RhB}][\mathrm{FL}]$ GUMBOS was used for $F_{\mathrm{da}}$ determination. The energy-transfer efficiency was calculated to be $66 \%$ in $\left[\mathrm{P}_{66614}\right][\mathrm{RhB}][\mathrm{FL}]$ GUMBOS, further suggesting excellent FRET.

2.4. Spectroscopic Analysis of NanoGUMBOS. Spectroscopic analyses were performed on $\left[\mathrm{P}_{66614}\right][\mathrm{RhB}][\mathrm{FL}]$ nanoparticles suspended in pure water to understand the formation of nanoGUMBOS and for later comparison with $\mathrm{pH}$-adjusted water. We found that the nano $\left[\mathrm{P}_{66614}\right][\mathrm{RhB}][\mathrm{FL}]$ absorbance spectrum (Figure 4) in pure water retained all

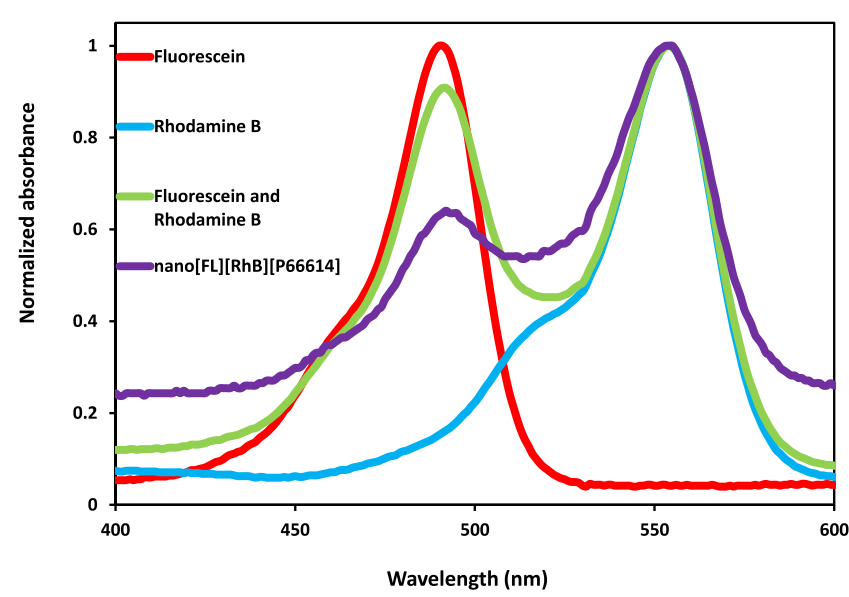

Figure 4. Normalized absorbance spectra of aqueous parent dyes FL and $\mathrm{RhB}$ in separate solutions, a solution containing both parent dyes, and $\left[\mathrm{P}_{66614}\right][\mathrm{RhB}][\mathrm{FL}]$ nanoGUMBOS in water.

features of the parent dyes. However, the absorbance value was significantly decreased in nanoGUMBOS as compared to parent dyes. Decreased and broadened absorbance is not unexpected with nanoparticle formation and can be attributed to aggregation, absence of motional narrowing, and asymmetric molecular arrangement (lattice disorder). ${ }^{29,37-40}$

Fluorescence emission spectra of parent dyes and nanoGUMBOS were obtained using an excitation wavelength of $495 \mathrm{~nm}$, that is, the maximum absorbance of FL in order for FRET to occur (Figure 5). As expected, RhB had a significantly lower fluorescence emission than FL because of

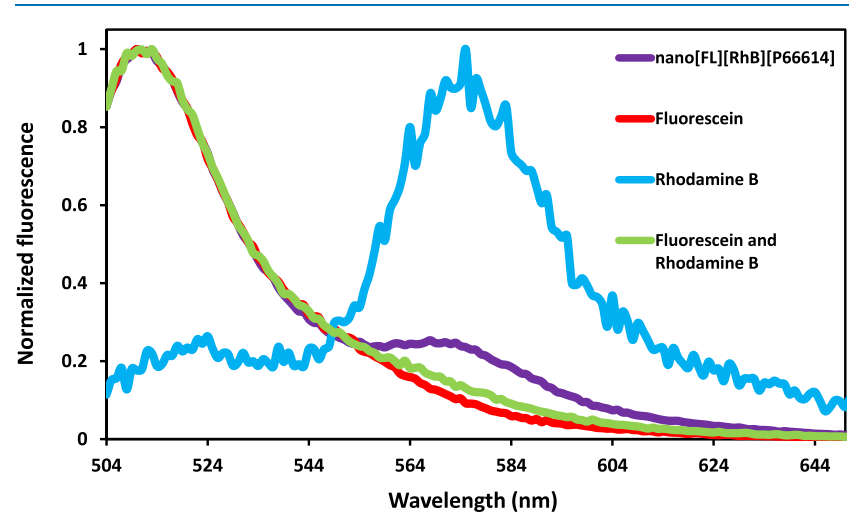

Figure 5. Normalized fluorescence emission spectra of aqueous parent dyes (FL and $\mathrm{RhB}$ ) in separate solutions, a solution containing both parent dyes, and $\left[\mathrm{P}_{66614}\right][\mathrm{RhB}][\mathrm{FL}]$ nanoparticles in water. $\lambda_{\mathrm{ex}}=$ $495 \mathrm{~nm}$. 
the low absorbance of $\mathrm{RhB}$ at $495 \mathrm{~nm}$. When an aqueous solution containing $\mathrm{FL}$ and $\mathrm{RhB}$ was excited at this wavelength, FL emission was quenched by approximately 9\% (from 761 000 to 696000 a.u.) and the peak area was reduced by approximately $8 \%$ (from 22800000 to 20900000 ).

Emission intensity corresponding to $\mathrm{RhB}$ emission maximum $(\lambda=575 \mathrm{~nm})$ is apparently enhanced from 25500 to 91 100 a.u. The peak area is seemingly enhanced from 1150000 to 5660000 . However, this emission was purely the sum of molecular FL and RhB emissions. The lack of enhancement in $\mathrm{RhB}$ emission suggested that an aqueous solution containing molecular FL and $\mathrm{RhB}$ did not undergo significant FRET. It can be discerned that FL and RhB were at sufficiently low concentrations or oriented in aqueous solution in a manner that inhibited FRET. NanoGUMBOS suspended in water and excited at $495 \mathrm{~nm}$ exhibited a significantly decreased FL emission. Fluorescein incorporated into nanoGUMBOS had emission quenched $78 \%$ relative to FL emission in free solution and a $70 \%$ decrease in the area. Rhodamine B emission was enhanced more than 14-fold as a component of nanoGUMBOS (from 25400 a.u. in free solution to 359000 a.u. in nanoGUMBOS), whereas the area of this peak increased approximately 17 -fold. Fluorescence of $\left[\mathrm{P}_{66614}\right][\mathrm{RhB}][\mathrm{FL}]$ nanoparticles in water also featured a distinct emission band for $\mathrm{RhB}$ emission at $570 \mathrm{~nm}$ that was not seen in a solution of a mixture of FL and $\mathrm{RhB}$ when excited at $495 \mathrm{~nm}$. Spectral properties thus indicated that in aqueous solutions, nanoparticles of $\left[\mathrm{P}_{66614}\right][\mathrm{RhB}][\mathrm{FL}]$ underwent FRET. The occurrence of FRET suggested that this three-component GUMBOS may be quite suitable for use as a FRET-based sensor.

2.5. Effect of $\mathrm{pH}$ on Spectral Properties of $\left[\mathrm{P}_{66614}\right]-$ [RhB][FL] NanoGUMBOS. Absorbance spectra of $\left[\mathrm{P}_{66614}\right]$ $[\mathrm{RhB}][\mathrm{FL}]$ nanoparticles over a wide range of $\mathrm{pH}$ values yielded information about the form of FL present at each $\mathrm{pH}$ (Figure 6A). The absorbance band at $550 \mathrm{~nm}$ corresponds to the RhB component of the nanoGUMBOS and remains largely unchanged across all $\mathrm{pH}$ values investigated. This pattern is comparable to known absorbance properties of molecular $\mathrm{RhB}^{41}$ Therefore, any $\mathrm{pH}$-dependent changes in $\mathrm{RhB}$ emission can be attributed to the association of $\mathrm{RhB}$ with FL and $\mathrm{P}_{66614}$. In practical applications of fluorescence-based measurements, a single excitation wavelength with dual emission wavelengths is typically more feasible than a dual excitation wavelength. ${ }^{42}$ For this reason, we have excited $\left[\mathrm{P}_{66614}\right][\mathrm{RhB}][\mathrm{FL}]$ nanoparticles at a single wavelength, namely, $495 \mathrm{~nm}$, and examined the resulting emission at seven different $\mathrm{pH}$ values (Figure 6B). Each spectrum in Figure 6 has been normalized to the maximum value in the experiment. For example, in Figure 6A, all spectra have been normalized to $\mathrm{pH} 7$ maximizing at 1 .

At $\mathrm{pH} 2,\left[\mathrm{P}_{66614}\right][\mathrm{RhB}][\mathrm{FL}]$ nanoparticles yielded an absorbance band at $437 \mathrm{~nm}$. This band was indicative of cationic FL. ${ }^{36}$ Interestingly, $\left[\mathrm{P}_{66614}\right][\mathrm{RhB}][\mathrm{FL}]$ nanoparticles at $\mathrm{pH} 2$ did not exhibit any other absorbance bands attributed to FL. This spectrum suggested that at $\mathrm{pH} \mathrm{2,} \mathrm{cationic} \mathrm{FL} \mathrm{was}$ the primary species in $\left[\mathrm{P}_{66614}\right][\mathrm{RhB}][\mathrm{FL}]$ nanoGUMBOS. The fluorescence emission band of $\left[\mathrm{P}_{66614}\right][\mathrm{RhB}][\mathrm{FL}]$ nanoparticles at $\mathrm{pH} 2$ has significantly lower intensity and area than at other $\mathrm{pH}$ values. This low emission was largely because of low absorbance of $\left[\mathrm{P}_{66614}\right][\mathrm{RhB}][\mathrm{FL}]$ at the selected excitation wavelength of $495 \mathrm{~nm}$ (characteristic of cationic $\mathrm{FL})$. The $\mathrm{RhB}$ emission band in nano $\left[\mathrm{P}_{66614}\right][\mathrm{RhB}][\mathrm{FL}]$ was significantly higher than that in the parent dye alone, indicating
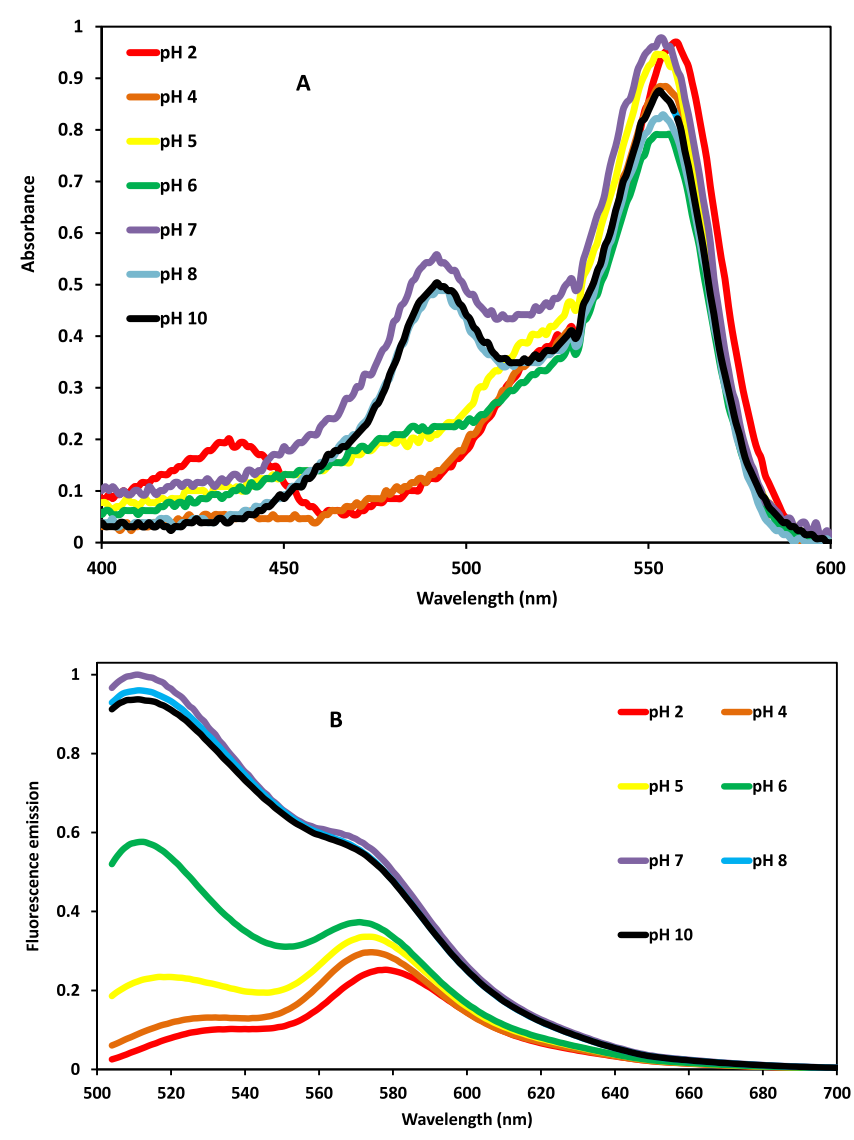

Figure 6. Spectral properties of $\left[\mathrm{P}_{66614}\right][\mathrm{RhB}][\mathrm{FL}]$ nanoGUMBOS in buffers of seven distinct $\mathrm{pH}$ values. (A) Absorbance spectra. (B) Fluorescence emission spectra. $\lambda_{\mathrm{ex}}=495 \mathrm{~nm}$.

the occurrence of FRET. The FL emission band of nano $\left[\mathrm{P}_{66614}\right][\mathrm{RhB}][\mathrm{FL}]$ in $\mathrm{pH} 2$ buffer was approximately 15 $\mathrm{nm}$ red-shifted from that of the parent compound. This shift is likely because of J-aggregation (i.e., head-to-tail stacking). ${ }^{43}$

Absorbance of $\left[\mathrm{P}_{66614}\right][\mathrm{RhB}][\mathrm{FL}]$ at $\mathrm{pH} 4$ suggested the presence of low FL concentration. Molecular FL with a neutral charge is known to exhibit very low absorbance (relative to charged forms) between approximately 430 and $480 \mathrm{~nm} .^{44}$ There was a broad absorbance band of very low intensity (between 0.05 and 0.1 units) from 460 to $490 \mathrm{~nm}$ that indicated slight absorbance of monoanionic FL. Molecular FL has a $\mathrm{pK}_{\mathrm{a}}$ of 4.31 for the transition from neutral to monoanionic form. Because $\mathrm{pH} 4$ is close to the $\mathrm{p} K_{\mathrm{a}}$ of $\mathrm{FL}$, it is not unexpected to see spectral contributions from both the neutral and monoanionic species. A previous study by Das et al. has also demonstrated stable nanomaterials composed of FL-based ionic materials with multiple protolytic forms of the FL present. ${ }^{28}$ Emission of nano $\left[\mathrm{P}_{66614}\right][\mathrm{RhB}][\mathrm{FL}]$ at $\mathrm{pH} 4$ was comparable to that at $\mathrm{pH}$ 2. The FL band again had low intensity and was red-shifted as compared to the parent dye and to other $\mathrm{pH}$ values. Low emission was again because of the low absorbance, as described earlier.

The $\left[\mathrm{P}_{66614}\right][\mathrm{RhB}][\mathrm{FL}]$ nanoparticles were absorbed broadly at $\mathrm{pH} 5$. Absorbance was relatively low (viz. between 0.1 and 0.2 ) and broad across the known absorbance wavelengths of FL. This spectrum and known FL $\mathrm{p} K_{\mathrm{a}}$ values suggested that at $\mathrm{pH} \mathrm{5}$, the monoanionic form of $\mathrm{FL}$ was present in nano $\left[\mathrm{P}_{66614}\right][\mathrm{RhB}][\mathrm{FL}]{ }^{45}$ Fluorescence emission intensity and peak area at the FL band $(515 \mathrm{~nm})$ increased 
from that of more acidic $\mathrm{pH}$ values because of increased absorbance of the monoanionic form and correspondingly higher molar extinction coefficient at the chosen excitation wavelength. ${ }^{44}$ Emission and peak area at the RhB band (575 $\mathrm{nm}$ ) was also increased from the more acidic environment of $\mathrm{pH}$ 2. This emission is not expected to change with $\mathrm{pH}$ when excited at $495 \mathrm{~nm}$. Therefore, this increase can be attributed to increased FRET resulting from a more intense FL emission. The emission at $\mathrm{pH} 5$ was not significantly shifted from the parent compound emission, indicating that J-aggregates were not prevalent at this $\mathrm{pH}$. It has previously been demonstrated that the protolytic form of FL participates in directing the prevalence and type of aggregation (i.e., $\mathrm{J}$ or $\mathrm{H}$ ). ${ }^{28}$

The absorbance spectrum of nano $\left[\mathrm{P}_{66614}\right][\mathrm{RhB}][\mathrm{FL}]$ at $\mathrm{pH}$ 6 was in broadness and intensity similar to the spectrum at $\mathrm{pH}$ 5 with two exceptions: at $\mathrm{pH} 6$, there was a slight increase (0.02 units) in the absorbance band at $485 \mathrm{~nm}$ and a significant decrease in apparent shouldering from $\mathrm{RhB}$ around $510 \mathrm{~nm}$. Fluorescein has a $\mathrm{p} K_{\mathrm{a}}$ of 6.45 between the mono- and dianionic forms. The closeness of $\mathrm{pH} 6$ to this $\mathrm{p} K_{\mathrm{a}}$ value likely resulted in multiple FL species as seen in the absorbance spectrum. The emission intensity and peak area of nano$\left[\mathrm{P}_{66614}\right][\mathrm{RhB}][\mathrm{FL}]$ at $\mathrm{pH} 6$ was significantly higher than at $\mathrm{pH}$ 5 for the FL band despite comparable absorbance at the excitation wavelength. Dianionic FL has significantly more intense fluorescence than monoanionic FL. ${ }^{45}$ Therefore, increased fluorescence intensity was likely due in part to the presence of dianionic $\mathrm{FL}$ in nano $\left[\mathrm{P}_{66614}\right][\mathrm{RhB}][\mathrm{FL}]$ at $\mathrm{pH} 6$. The emission band corresponding to $\mathrm{RhB}$ was only slightly more intense than that of $\mathrm{pH} \mathrm{5}$, although the peak area increased to approximately $10 \%$. This contrast in spectra strongly suggested that FRET decreased at $\mathrm{pH}$ 6. Transmission electron microscopy (TEM) images revealed that at $\mathrm{pH} 6$, nano $\left[\mathrm{P}_{66614}\right][\mathrm{RhB}][\mathrm{FL}]$ had a slight solubility. The expansion of nanoparticles at this $\mathrm{pH}$ increased the distance between FL and RhB components to reduce the FRET efficiency. Decreased FRET would also have contributed to a more intense (less quenched) emission at the FL band.

Spectral properties of nano $\left[\mathrm{P}_{66614}\right][\mathrm{RhB}][\mathrm{FL}]$ did not differ significantly between $\mathrm{pH}$ values of 7 and 10 . Between these $\mathrm{pH}$ values, molecular FL remains dianionic. The intense absorbance band at $495 \mathrm{~nm}$ indicated that dianionic FL was the primary species present in nanoGUMBOS at these $\mathrm{pH}$ values. As predicted, intense absorbance at the excitation wavelength resulted in significantly more intense fluorescence emission at $510 \mathrm{~nm}$ than seen at other $\mathrm{pH}$ values. The fluorescence band corresponding to $\mathrm{RhB}$ was almost twice the intensity of the band in more acidic environments. However, intensity of the rhodamine band was only $60 \%$ of the FL band. The varied absorbance of $\mathrm{FL}$ within $\left[\mathrm{P}_{66614}\right][\mathrm{RhB}][\mathrm{FL}]$ nanoparticles at different $\mathrm{pH}$ values and apparent differences in fluorescence intensities suggested that this GUMBOS can be used for $\mathrm{pH}$-dependent emission at a single excitation wavelength.

Ratiometric calculations can be used for an intrinsically calibrated determination of $\mathrm{pH}$ values, as previously discussed. ${ }^{46,47}$ The ratio of intensities was calculated between 512 and $575 \mathrm{~nm}$. As depicted in Figure 7, the linearity of ratiometric $\mathrm{pH}$ response of $\left[\mathrm{P}_{66614}\right][\mathrm{RhB}][\mathrm{FL}]$ nanoparticles was between approximate $\mathrm{pH}$ values of 5 and 7 . This $\mathrm{pH}$ range aligns well with the desire for cellular $\mathrm{pH}$ determination. Ratiometric analysis cannot be used with this material to differentiate $\mathrm{pH}$ values between 2 and 4 or between 7 and 10 .

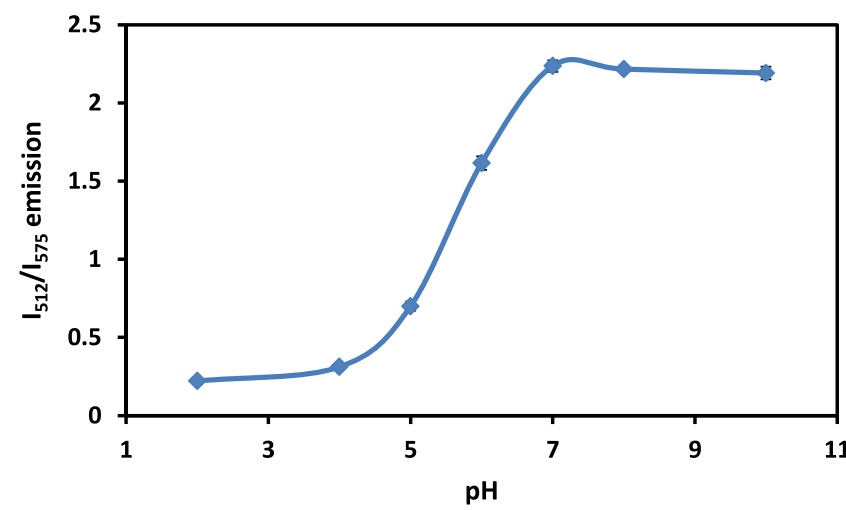

Figure 7. Ratio of fluorescence emission intensities at 512 and 575 $\mathrm{nm}$. These wavelengths correspond to emission from the FL component and the $\mathrm{RhB}$ component, respectively.

However, this material can be used for a qualitative analysis of $\mathrm{pH}$ values lower or higher than the linear range. For example, a ratio of 0.22 could indicate acidity too high for normal cells but would not allow quantification of $\mathrm{pH}$ in the cells.

2.6. Size Analysis of $\left[P_{66614}\right][F L][R h B]$ NanoGUMBOS. Nanoparticles composed of $[\mathrm{P} 66614][\mathrm{RhB}][\mathrm{FL}]$ were synthesized in pure water using a reprecipitation method. As can be seen from Figure 8A, uniform size distribution of nanoparticles with an average size of $4.4 \pm 0.7 \mathrm{~nm}$ was observed using TEM micrograph analyses. When these particles were injected into buffer solutions at various $\mathrm{pH}$ values, size distributions of nanoparticles were found to differ for different environmental acidities, especially at extreme $\mathrm{pH}$ values (viz. 2 and 10). It has previously been shown that both the protolytic form of $\mathrm{FL}^{28}$ (where applicable) and several types of interactions (covalent and noncovalent $)^{48}$ impact molecular arrangement of nanoparticles and can impart $\mathrm{pH}$-induced size changes. At $\mathrm{pH} 2$, molecular FL exists in the cationic form. ${ }^{44}\left[\mathrm{P}_{66614}\right][\mathrm{RhB}][\mathrm{FL}]$ nanoparticles injected into the $\mathrm{pH} 2$ buffer coalesce into significantly larger particles of $69.7 \pm 8.1 \mathrm{~nm}$ (Figure 8B). Relatively large nanoparticles suggested that the presence of cationic FL (as seen in absorbance spectrum, Figure 6A) exhibited sufficient repulsion with $\mathrm{P}_{66614}$ cations to increase the particle size. Such changes in size because of intraparticle interactions with $\mathrm{pH}$ have previously been described in detail. ${ }^{28}$ Despite this significant size and repulsion increase, particles are uniformly sized with a spherical shape.

Between $\mathrm{pH} 4$ and 8 , the $\left[\mathrm{P}_{66614}\right][\mathrm{RhB}][\mathrm{FL}]$ nanoparticle size was not significantly altered upon injection into buffer solutions (relative to suspension in water). Nanoparticles at $\mathrm{pH} 4$ were found to be $4.3 \pm 0.7 \mathrm{~nm}$ (Figure $8 \mathrm{C}$ ). Molecular FL would be neutral at this $\mathrm{pH}$ value. The presence of neutral FL species is supported by the absorbance spectrum (Figure $6 \mathrm{~A})$. Interestingly, no significant size difference was observed at $\mathrm{pH} 4$ as compared to pure water. Neutral FL would not be expected to have significant intraparticle repulsion effects with cationic components. Therefore, size preservation further supported the theory that the nanoparticle size is partially driven by the protolytic form of FL and the resulting intraparticle interactions.

Between $\mathrm{pH}$ values of 5 and 6 , molecular FL would be monodeprotonated. $\left[\mathrm{P}_{66614}\right][\mathrm{RhB}][\mathrm{FL}]$ nanoparticles were found to aggregate into a network of material at these $\mathrm{pH}$ values (Figure $8 \mathrm{D}, \mathrm{E}$ ). Within many of these networks of material, particles of approximately $4-5 \mathrm{~nm}$ were retained. 


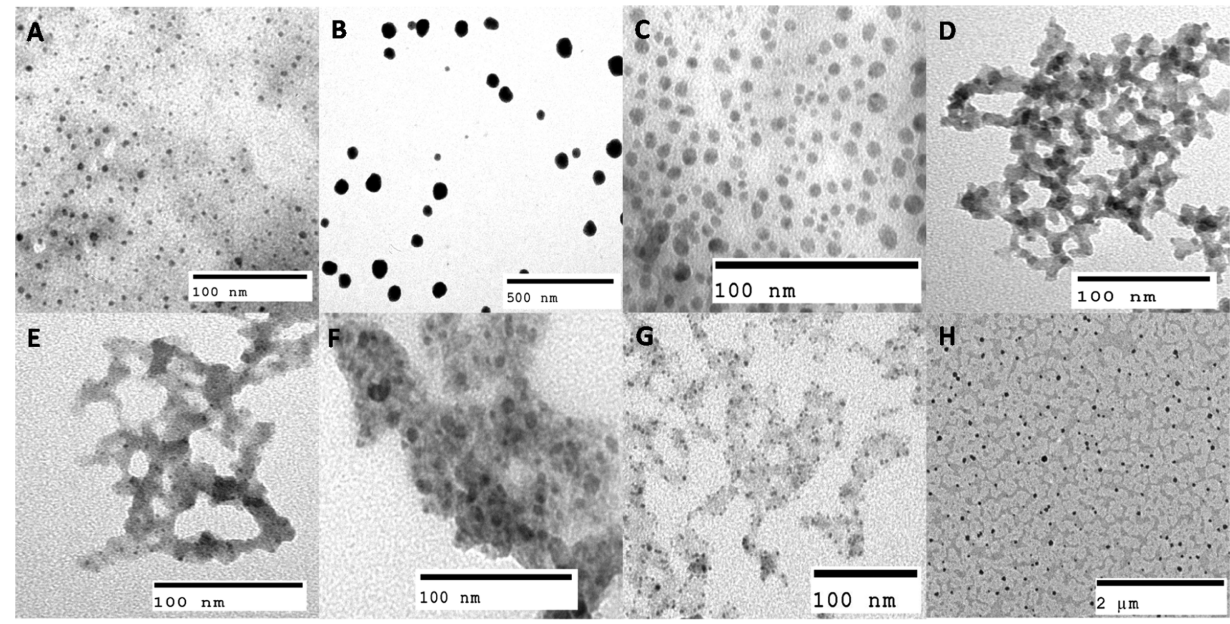

Figure 8. TEM micrographs of $\left[\mathrm{P}_{66614}\right][\mathrm{RhB}][\mathrm{FL}]$ nanoGUMBOS in (A) pure water, (B) $\mathrm{pH} 2,(\mathrm{C}) \mathrm{pH} 4,(\mathrm{D}) \mathrm{pH} \mathrm{5,} \mathrm{(E)} \mathrm{pH} \mathrm{6,} \mathrm{(F)} \mathrm{pH} \mathrm{7,} \mathrm{(G)} \mathrm{pH}$ 8 , and $(\mathrm{H}) \mathrm{pH} 10$.

However, boundaries of nanomaterials were indistinct. $\left[\mathrm{P}_{66614}\right][\mathrm{RhB}][\mathrm{FL}]$ appeared to be slightly soluble at these $\mathrm{pH}$ values, thereby decreasing the nanoparticle stability. A buffer of $\mathrm{pH} 7$ resulted in distinct particles embedded into a network of material (Figure 8F). However, at $\mathrm{pH} 7$, particles could be more clearly distinguished from the surrounding network than at $\mathrm{pH} 5$ and 6 . The average particle size found in the network of $\mathrm{pH} 7$ was $\approx 4.2 \pm 0.5 \mathrm{~nm}$, statistically equivalent in size to particles in pure water. $\mathrm{A} \mathrm{pH}$ value of 8 also resulted in particles of size and shape (Figure $8 \mathrm{G}$ ) similar to those formed in pure water (viz. $3.8 \pm 0.6 \mathrm{~nm}$ ). Molecular $\mathrm{FL}$ is dianionic at both $\mathrm{pH} 7$ and 8 . The two negative charges strongly interacted with cationic $\mathrm{RhB}$ and $\mathrm{P}_{66614}$ to retain GUMBOS and nanoparticle association at these $\mathrm{pH}$ values. Interestingly, this size stability was not seen at $\mathrm{pH} 10$ (Figure $8 \mathrm{H})$. It was observed that basic $\mathrm{pH} 10$ resulted in coalescence of $\left[\mathrm{P}_{66614}\right][\mathrm{RhB}][\mathrm{FL}]$ nanoparticles into larger particles of 71.0 $\pm 11.0 \mathrm{~nm}$. The substantial increase in hydroxide ions between a $\mathrm{pH} 8$ solution and a $\mathrm{pH} 10$ solution resulted in a more favorable environment for a combination of $4 \mathrm{~nm}\left[\mathrm{P}_{66614}\right]$ $[\mathrm{RhB}][\mathrm{FL}]$ particles into larger diameter particles.

2.7. $\left[P_{66614}\right][R h B][F L]$ NanoGUMBOS for Fluorescence Microscopy Imaging of Cancer Cells. The significant differences between fluorescence peak ratios at $\mathrm{pH} 5$ and $\mathrm{pH} 7$ (0.70 and 2.2, respectively) implied that $\left[\mathrm{P}_{66614}\right][\mathrm{RhB}][\mathrm{FL}]$ nanoparticles could be useful for cancer imaging applications. Fluorescence microscopy filters can be selected to pass FL emission and $\mathrm{RhB}$ emission separately. In this case, measured intensities (from each filter) can be used to ratiometrically determine the $\mathrm{pH}$ in situ. This analysis is strongly beneficial not only for cancer detection but may also be useful for other human conditions involved in $\mathrm{pH}$ change (e.g., infections).

Two cell lines, normal human breast cells, and cancerous human breast cells were incubated with $25 \mathrm{nM}\left[\mathrm{P}_{66614}\right][\mathrm{RhB}]$ [FL] nanoparticles. Control studies were done with equivalent concentrations of parent dyes (Figure 9A,B). Fluorescence microscopy images were obtained using a TRITC filter $\left(\lambda_{\mathrm{ex}}=\right.$ $535 \pm 15 \mathrm{~nm}$ and $\left.\lambda_{\mathrm{em}}=575 \pm 15 \mathrm{~nm}\right)$ and a differential interference contrast (DIC) polarizing filter. A clear visual distinction could be made between normal and cancer cells incubated with nano[ $\left[\mathrm{P}_{66614}\right][\mathrm{RhB}][\mathrm{FL}]$ (Figure 9C). Cancer cells exhibited an intense fluorescence throughout the entire cell, except the nucleus. Normal cells exhibited significantly less

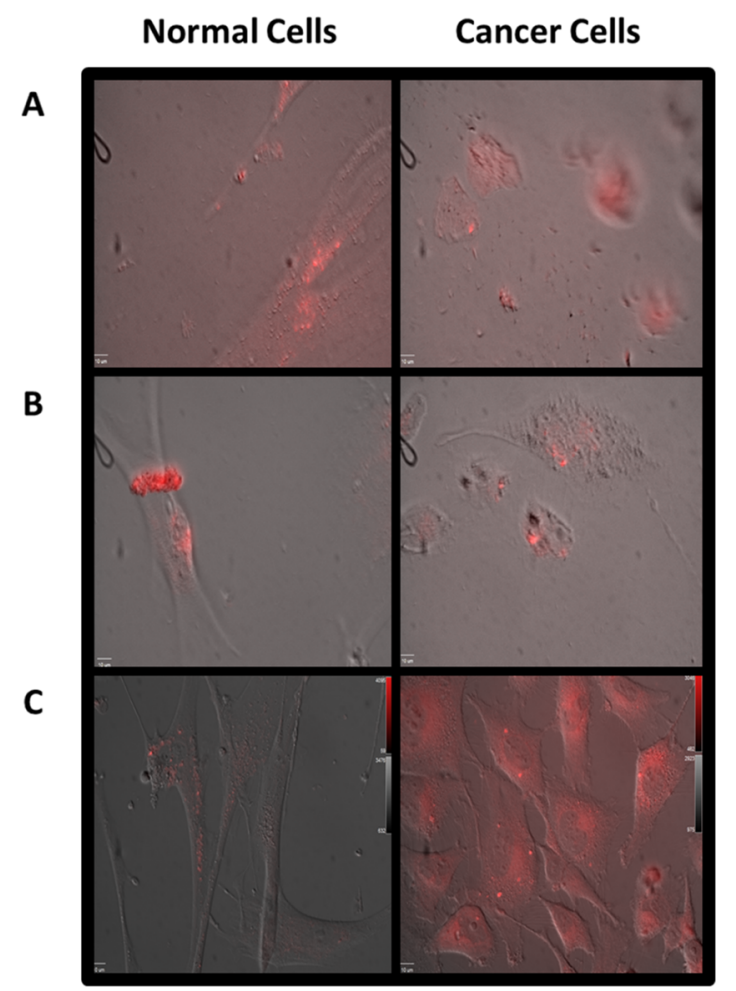

Figure 9. Fluorescence microscopy images of $25 \mathrm{nM}$ parent dyes and sensor in normal and cancerous breast cells. All images have TRITC $\left(\lambda_{\mathrm{ex}}=535 \pm 15 \mathrm{~nm}, \lambda_{\mathrm{em}}=575 \pm 15 \mathrm{~nm}\right)$ and DIC (polarizing) filters applied for visualization of cells. (A) FL, (B) $\mathrm{RhB}$, and (C) $\left[\mathrm{P}_{66614}\right][\mathrm{RhB}][\mathrm{FL}]$ nanoGUMBOS. All scale bars represent $10 \mu \mathrm{m}$.

distribution of fluorescence than cancer cells, where only scattered fluorescence can be seen. Studies of parent dye FL showed that the incubation in normal and cancer cells both resulted in fluorescence throughout the cell. Studies of parent dye $\mathrm{RhB}$ showed that the incubation in normal and cancer cells both resulted in localized fluorescence in the nucleus. Comparison of $\left[\mathrm{P}_{66614}\right][\mathrm{RhB}][\mathrm{FL}]$ nanoGUMBOS to parent dyes revealed that the formation of nanoGUMBOS produces differentiation of cellular uptake between cancerous and normal cells and, effectually, observed fluorescence. This substantial visual difference indicated that $\left[\mathrm{P}_{66614}\right][\mathrm{RhB}][\mathrm{FL}]$ 
nanoGUMBOS may be useful in the imaging of cancer cells, especially because of the ease and speed required for visual diagnostic analyses.

2.8. Photostability and Thermostability of $\left[P_{66614}\right]-$ [RhB][FL]. Photostability is an important characteristic of dyes used for biomedical imaging. ${ }^{49,50}$ High photostability in a material results in longer shelf-life and more reproducible measurements over time. As depicted in Figure 10A, an

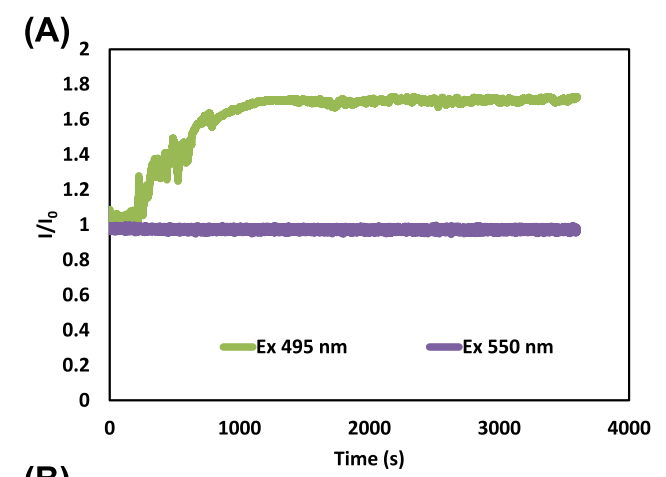

(B)

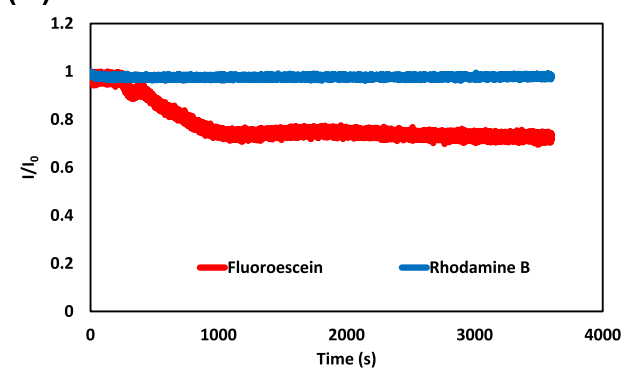

Figure 10. Photostability (A) FL and $\mathrm{RhB}\left(\lambda_{\mathrm{ex}}=495 \mathrm{~nm}\right)$. (B) $\left[\mathrm{P}_{66614}\right][\mathrm{RhB}][\mathrm{FL}]\left(\lambda_{\mathrm{ex}}=495,550 \mathrm{~nm}\right)$.

exceptional photostability of $\left[\mathrm{P}_{66614}\right][\mathrm{RhB}][\mathrm{FL}]$ GUMBOS has been observed with an increase of $170 \%$ over the first $11000 \mathrm{~s}$. From 11000 to $36000 \mathrm{~s}$, the photostability was nearly constant at $170 \%$. Fluorescein was reduced to $74 \%$ and $\mathrm{RhB}$ remained at $98 \%$ over the same time period (Figure 10B). However, the lack of photobleaching in the case of $\mathrm{RhB}$ is presumably because of the insignificant absorbance at the chosen excitation wavelength. Increased photostability has also been observed in previous studies where $\mathrm{Lu}$, et al. ascribed this increased photostability to laser-induced J-aggregation. ${ }^{28,51}$ This increase in fluorescence emission with light exposure provides a strong advantage for practical use of $\left[\mathrm{P}_{66614}\right][\mathrm{RhB}][\mathrm{FL}]$, especially for fluorescence imaging. Thermal stability is another important characteristic of materials exposed to lasers. $\left[\mathrm{P}_{66614}\right][\mathrm{RhB}][\mathrm{FL}]$ was found to be thermally stable ( $90 \%$ weight retention) up to $299{ }^{\circ} \mathrm{C}$ (Figure S3).

\section{CONCLUSIONS}

In this study, we have demonstrated the synthesis of $\left[\mathrm{P}_{66614}\right][\mathrm{RhB}][\mathrm{FL}]$, a three-component GUMBOS composed of FL, RhB, and tetradecyltrihexyl phosphonium. NanoGUMBOS was found to have relatively consistent sizes of approximately $4 \mathrm{~nm}$ with changes in $\mathrm{pH}$. However, in the case of very acidic or very basic conditions (i.e., $\mathrm{pH} 2$ and 10 respectively), particles were significantly larger (approximately $70 \mathrm{~nm})$. Nano $\left[\mathrm{P}_{66614}\right][\mathrm{RhB}][\mathrm{FL}]$ exhibited $\mathrm{pH}$-dependent spectral properties. Absorbance spectra of the nanoGUMBOS indicated that the protolytic form of FL within the nanoparticle corresponded to that of FL in solution. Fluorescence emission of nano $\left[\mathrm{P}_{66614}\right][\mathrm{RhB}][\mathrm{FL}]$ exhibited two bands corresponding to $\mathrm{FL}$ and $\mathrm{RhB}$. Both bands increased with increasing values of $\mathrm{pH}$ because of the enhanced absorbance in more anionic forms of FL and increased FRET, with the exception of $\mathrm{pH} 6$. FRET was slightly decreased at this value of $\mathrm{pH}$ because of slight solubility. Intramolecular FRET yielded a fluorescent peak ratio that varied significantly between $\mathrm{pH} 5$ and $\mathrm{pH} 7$, an essential range for cellular $\mathrm{pH}$ sensing. Cancer cells incubated with $\left[\mathrm{P}_{66614}\right][\mathrm{RhB}][\mathrm{FL}]$ nanoparticles were found to have a greater selective distribution of fluorescence over normal cells incubated under equivalent experimental conditions. Such a differentiation could not be made with equivalently analyzed parent compounds. This visual difference shows an enhanced potential for the use of $\left[\mathrm{P}_{66614}\right][\mathrm{RhB}][\mathrm{FL}]$ nanoGUMBOS in the visual detection of cancer.

\section{MATERIALS AND METHODS}

4.1. Materials. Disodium FL ( $\geq 97.5 \%), \mathrm{RhB}(\geq 95 \%)$, and tetradecyltrihexyl phosphonium chloride $\left(\left[\mathrm{P}_{66614}\right][\mathrm{Cl}]\right)$ $(\geq 95 \%)$ were purchased from Sigma-Aldrich and used as received. Dichloromethane (DCM) $(\geq 99.9 \%)$ was purchased from Fisher Scientific and also used as received. Water used in all experiments is triply deionized $(18 \mathrm{M} \Omega \mathrm{cm})$ and obtained from an Aries Filterworks high-purity water system.

4.2. Synthesis of GUMBOS. $\left[\mathrm{P}_{66614}\right][\mathrm{RhB}][\mathrm{FL}]$ GUMBOS was synthesized using a stepwise reaction. Initially, $\left[\mathrm{P}_{66614}\right][\mathrm{FL}]$ GUMBOS was synthesized based on a procedure described elsewhere. ${ }^{28}$ Thereafter, the required $\left[\mathrm{P}_{66614}\right][\mathrm{RhB}]$ [FL] GUMBOS was synthesized by the use of ion exchange. The comprehensive reaction scheme is provided in Supporting Information, Figure S1. In brief, disodium FL was dissolved in $\mathrm{pH} 5.5$ citrate buffer, resulting in a monoanionic species. $\left[\mathrm{P}_{66614}\right][\mathrm{Cl}]$ in DCM was added using a $1: 1.1 \mathrm{M}$ ratio $\left(\mathrm{P}_{66614} \backslash \mathrm{FL}\right)$ to aqueous $\mathrm{FL}$ and allowed to stir for $48 \mathrm{~h}$. After stirring, FL could be distinguished prominently in the DCM layer via its well-known green color. Excess FL remained unreacted as evidenced by slight coloration of the water layer. This transfer suggested that FL was ionically associated with the phosphonium cation to form a water-insoluble salt. The DCM layer was washed several times with water to remove excess unreacted $\mathrm{FL}$ and $\mathrm{NaCl}$ byproduct. Aqueous $\mathrm{RhB}$ was added in a 1.1:1 molar ratio $\left(\mathrm{RhB} \backslash[\mathrm{FL}]\left[\mathrm{P}_{66614}\right]\right)$ and left to stir for $48 \mathrm{~h}$ until $\mathrm{RhB}$ was no longer prominent in the water layer. The water layer containing unreacted excess $\mathrm{RhB}$ was removed. The DCM layer was washed with water several times to remove any unreacted $\mathrm{RhB}$ and byproduct. The final product was obtained by removing DCM through rotary evaporation. The sample was subsequently lyophilized to remove excess water. The synthesis of $\left[\mathrm{P}_{66614}\right][\mathrm{RhB}][\mathrm{FL}]$ GUMBOS was confirmed by the use of a Bruker 400 NanoBay NMR (Figure S2). Thermal gravimetric analysis was performed (Figure S3) using a TA Instruments TGA 2950 (TA Instruments, New Castle, DE).

4.3. Synthesis of NanoGUMBOS. NanoGUMBOS were synthesized using a reprecipitation method in which $60 \mu \mathrm{L}$ of 1 $\mathrm{mM}$ ethanolic GUMBOS solution was added to $3 \mathrm{~mL}$ of water under sonication. For $\mathrm{pH}$ studies, nanoGUMBOS synthesized in water was injected into the buffer of desired $\mathrm{pH}$ for a final concentration of $2 \mu \mathrm{M}$. Size and morphology of the resulting nanoGUMBOS were characterized using a JEOL1011CX transmission electron microscope (JEOL USA, Inc., Munich, Germany). 
4.4. Spectroscopic Studies of GUMBOS and NanoGUMBOS. Absorbance studies were performed using a Shimadzu UV-3101PC UV-vis-NIR scanning spectrometer (Shimadzu, Columbia, MD). Quartz cuvettes (Starna cells) with a $0.4 \mathrm{~cm}$ path length were used for all spectral analyses. For acquisition of absorbance spectra, an identical cell was filled with water or buffer, as the case may be, and used as reference. Fluorescent emission spectra were obtained using a FluoroLog-3 spectrofluorimeter (model FL3-22TAU3; HORIBA Scientific, Edison, NJ) with $1 \mathrm{~nm}$ slit widths while employing the right-angle geometry.

4.5. Cell Culture. Normal human breast fibroblast (Hs578BST, ATCC no. HTB-125) and human breast carcinoma (Hs578T, ATCC no. HTB-126) cell lines were obtained from American Type Culture Collection (ATCC, Manassas, VA) and grown to $90 \%$ confluence at $37{ }^{\circ} \mathrm{C}$ and $5 \%$ $\mathrm{CO} 2$ in Dulbecco's modified Eagle media (DMEM) supplemented with 10\% FBS according to ATCC guidelines.

4.6. Fluorescence Microscopy. Five thousand cells of each cell line (normal breast and breast carcinoma) were plated in $3 \mathrm{~mL}$ of DMEM cell media containing 10\% FBS on a $25 \mathrm{~mm}$ glass bottom Petri dish (10 mm micro cell; Ashland, MA, USA) and incubated for $24 \mathrm{~h}$. Following incubation, the cell culture media was replaced with cell media containing suspended $25 \mathrm{nM}$ [P66614][RhB][FL] nanoGUMBOS and incubated for an additional $30 \mathrm{~min}$. Fluorescence microscopy images were captured using a fluorescence microscope (Leica, TCS SP5, Mannheim, Germany) and a 40X dipping objective lens with a TRITC fluorescence filter with $\lambda_{\text {ex }}=535 \pm 15 \mathrm{~nm}$ and $\lambda_{\mathrm{em}}=575 \pm 15 \mathrm{~nm}$ and DIC polarization. All fluorescence images were captured using $5000 \mathrm{~s}$ exposure time for consistency.

\section{ASSOCIATED CONTENT}

\section{S Supporting Information}

The Supporting Information is available free of charge on the ACS Publications website at DOI: 10.1021/acsomega.8b02765.

Reaction scheme of [P66614][RhB][FL] GUMBOS synthesis, NMR comparison of $[\mathrm{P} 66614][\mathrm{RhB}][\mathrm{FL}]$ GUMBOS with parent compounds, and thermogravimetric analysis of [P66614][RhB][FL] GUMBOS (PDF)

\section{AUTHOR INFORMATION}

\section{Corresponding Author}

*E-mail: iwarner@lsu.edu.

\section{ORCID}

Isiah M. Warner: 0000-0002-5336-7653

Notes

The authors declare no competing financial interest.

\section{ACKNOWLEDGMENTS}

This material is based upon work supported by the National Science Foundation under grant no. CHE-1508726. Any opinions, findings, and conclusions or recommendations expressed in this material are those of the author(s) and do not necessarily reflect the views of the National Science Foundation.

\section{REFERENCES}

(1) Damaghi, M.; Wojtkowiak, J. W.; Gillies, R. J. pH sensing and regulation in cancer. Front. Physiol. 2013, 4, 370.

(2) Gillies, R. J.; Raghunand, N.; Garcia-Martin, M. L.; Gatenby, R. A. pH imaging. IEEE Eng. Med. Biol. Mag. 2004, 23, 57-64.

(3) Robey, I. F.; Baggett, B. K.; Kirkpatrick, N. D.; Roe, D. J.; Dosescu, J.; Sloane, B. F.; Hashim, A. I.; Morse, D. L.; Raghunand, N.; Gatenby, R. A.; Gillies, R. J. Bicarbonate increases tumor $\mathrm{pH}$ and inhibits spontaneous metastases. Cancer Res. 2009, 69, 2260-2268.

(4) Mahmood, H. S.; Hoogmoed, W. B.; van Henten, E. J. Sensor data fusion to predict multiple soil properties. Precis. Agric. 2012, 13, 628-645.

(5) Dutta, S.; Sarma, D.; Nath, P. Ground and river water quality monitoring using a smartphone-based $\mathrm{pH}$ sensor. AIP Adv. 2015, 5, 057151.

(6) Schreml, S.; Meier, R. J.; Weiß, K. T.; Cattani, J.; Flittner, D.; Gehmert, S.; Wolfbeis, O. S.; Landthaler, M.; Babilas, P. A sprayable luminescent $\mathrm{pH}$ sensor and its use for wound imaging in vivo. Exp. Dermatol. 2012, 21, 951-953.

(7) John, G. T.; Goelling, D.; Klimant, I.; Schneider, H.; Heinzle, E. $\mathrm{pH}$-sensing 96-well microtitre plates for the characterization of acid production by dairy starter cultures. J. Dairy Res. 2003, 70, 327-333.

(8) Kang, T.; Xie, Z.-Y.; Tang, H.; Shen, G.L.; Yu, R.Q. Potentiometric $\mathrm{pH}$ sensors based on chemically modified electrodes with electropolymerized metal-tetraaminophthalocyanine. Talanta 1997, 45, 291-296.

(9) Schöning, M. J.; Brinkmann, D.; Rolka, D.; Demuth, C.; Poghossian, A. CIP (cleaning-in-place) suitable "non-glass" pH sensor based on a Ta2O5-gate EIS structure. Sens. Actuators, B 2005, 111112, 423-429.

(10) Gao, F.; Tang, L.; Dai, L.; Wang, L. A fluorescence ratiometric nano-pH sensor based on dual-fluorophore-doped silica nanoparticles. Spectrochim. Acta, Part A 2007, 67, 517-521.

(11) Zhang, X.; Jing, S.-Y.; Huang, S.-Y.; Zhou, X.-W.; Bai, J.-M.; Zhao, B.-X. New fluorescent $\mathrm{pH}$ probes for acid conditions. Sens. Actuators, B 2015, 206, 663-670.

(12) Sapsford, K. E.; Berti, L.; Medintz, I. L. Materials for fluorescence resonance energy transfer analysis: beyond traditional donor-acceptor combinations. Angew. Chem., Int. Ed. 2006, 45, $4562-4589$.

(13) Lu, F.; Wu, S.-H.; Hung, Y.; Mou, C.-Y. Size effect on cell uptake in well-suspended, uniform mesoporous silica nanoparticles. Small 2009, 5, 1408-1413.

(14) Zhou, K.; Wang, Y.; Huang, X.; Luby-Phelps, K.; Sumer, B. D.; Gao, J. Tunable, Ultrasensitive pH-Responsive Nanoparticles Targeting Specific Endocytic Organelles in Living Cells. Angew. Chem., Int. Ed. 2011, 50, 6109-6114.

(15) Brasuel, M.; Kopelman, R.; Miller, T. J.; Tjalkens, R.; Philbert, M. A. Fluorescent nanosensors for intracellular chemical analysis: decyl methacrylate liquid polymer matrix and ion-exchange-based potassium PEBBLE sensors with real-time application to viable rat $\mathrm{C} 6$ glioma cells. Anal. Chem. 2001, 73, 2221-2228.

(16) Burns, A.; Sengupta, P.; Zedayko, T.; Baird, B.; Wiesner, U. Core/Shell Fluorescent Silica Nanoparticles for Chemical Sensing: Towards Single-Particle Laboratories. Small 2006, 2, 723-726.

(17) Gao, F.; Wang, L.; Tang, L.; Zhu, C. A Novel Nano-Sensor Based on Rhodamine- $\beta$-Isothiocyanate - Doped Silica Nanoparticle for $\mathrm{pH}$ Measurementr. Microchim. Acta 2005, 152, 131-135.

(18) Qiao, Y.; Xu, T.; Zhang, Y.; Zhang, C.; Shi, L.; Zhang, G.; Shuang, S.; Dong, C. Green synthesis of fluorescent copper nanoclusters for reversible pH-sensors. Sens. Actuators, B 2015, 220, 1064-1069.

(19) Shi, W.; Li, X.; Ma, H. A Tunable Ratiometric pH Sensor Based on Carbon Nanodots for the Quantitative Measurement of the Intracellular $\mathrm{pH}$ of Whole Cells. Angew. Chem. 2012, 124, 65386541.

(20) Wu, Y.-X.; Zhang, X.-B.; Li, J.-B.; Zhang, C.-C.; Liang, H.; Mao, G.-J.; Zhou, L.-Y.; Tan, W.; Yu, R.-Q. Bispyrene-Fluorescein Hybrid Based FRET Cassette: A Convenient Platform toward Ratiometric 
Time-Resolved Probe for Bioanalytical Applications. Anal. Chem. 2014, 86, 10389-10396.

(21) Han, J.; Burgess, K. Fluorescent indicators for intracellular $\mathrm{pH}$. Chem Rev 2010, 110, 2709-28.

(22) Shaked, N. T.; Rinehart, M. T.; Wax, A. Dual-interferencechannel quantitative-phase microscopy of live cell dynamics. Opt. Lett. 2009, 34, 767-769.

(23) Kermis, H. R.; Kostov, Y.; Harms, P.; Rao, G. Dual Excitation Ratiometric Fluorescent $\mathrm{pH}$ Sensor for Noninvasive Bioprocess Monitoring: Development and Application. Biotechnol. Prog. 2002, 18, 1047-1053.

(24) Hong, S. W.; Jo, W. H. A fluorescence resonance energy transfer probe for sensing $\mathrm{pH}$ in aqueous solution. Polymer 2008, 49, $4180-4187$.

(25) Wang, X.-d.; Meier, R. J.; Wolfbeis, O. S. Fluorescent pHSensitive Nanoparticles in an Agarose Matrix for Imaging of Bacterial Growth and Metabolism. Angew. Chem. 2012, 125, 424-427.

(26) Meier, R. J.; Simbürger, J. M.; Soukka, T.; Schäferling, M. A FRET based $\mathrm{pH}$ probe with a broad working range applicable to referenced ratiometric dual wavelength and luminescence lifetime read out. Chem. Commun. 2015, 51, 6145-6148.

(27) Warner, I. M.; El-Zahab, B.; Siraj, N. Perspectives on Moving Ionic Liquid Chemistry into the Solid Phase. Anal 2014, 86, 71847191.

(28) Das, S.; Magut, P. K. S.; de Rooy, S. L.; Hasan, F.; Warner, I. $\mathrm{M}$. Ionic liquid-based fluorescein colorimetric $\mathrm{pH}$ nanosensors. $R S C$ Adv. 2013, 3, 21054-21061.

(29) Jordan, A. N.; Das, S.; Siraj, N.; de Rooy, S. L.; Li, M.; ElZahab, B.; Chandler, L.; Baker, G. A.; Warner, I. M. Anion-controlled morphologies and spectral features of cyanine-based nanoGUMBOSan improved photosensitizer. Nanoscale 2012, 4, 5031-5038.

(30) Siraj, N.; Hasan, F.; Das, S.; Kiruri, L. W.; Gall, K. E. S.; Baker, G. A.; Warner, I. M. Carbazole-Derived Group of Uniform Materials Based on Organic Salts: Solid State Fluorescent Analogues of Ionic Liquids for Potential Applications in Organic-Based Blue LightEmitting Diodes. J. Phys. Chem. C 2014, 118, 2312-2320.

(31) Regmi, B. P.; Monk, J.; El-Zahab, B.; Das, S.; Hung, F. R.; Hayes, D. J.; Warner, I. M. A novel composite film for detection and molecular weight determination of organic vapors. J. Mater. Chem. 2012, 22, 13732-13741.

(32) Galpothdeniya, W. I. S.; Regmi, B. P.; McCarter, K. S.; de Rooy, S. L.; Siraj, N.; Warner, I. M. Virtual Colorimetric Sensor Array: Single Ionic Liquid for Solvent Discrimination. Anal. Chem. 2015, 87, 4464-4471.

(33) Magut, P. K. S.; Das, S.; Fernand, V. E.; Losso, J.; McDonough, K.; Naylor, B. M.; Aggarwal, S.; Warner, I. M. Tunable Cytotoxicity of Rhodamine 6G via Anion Variations. J. Am. Chem. Soc. 2013, 135, 15873-15879.

(34) Saini, S.; Singh, H.; Bagchi, B. Fluorescence resonance energy transfer (FRET) in chemistry and biology: Non-Förster distance dependence of the FRET rate. J. Chem. Sci. 2006, 118, 23-35.

(35) Cong, M.; Siraj, N.; Bhattarai, N.; Kolic, P. E.; McCarter, K. S.; Chhotaray, P. K.; Warner, I. M. Ratiometric fluorescence detection of hydroxyl radical using cyanine-based binary nanoGUMBOS. Sens. Actuators, B 2018, 257, 993-1000.

(36) Margulies, D.; Melman, G.; Shanzer, A. Fluorescein as a model molecular calculator with reset capability. Nat. Mater. 2005, 4, 768771.

(37) An, B.-K.; Kwon, S.-K.; Jung, S.-D.; Park, S. Y. Enhanced emission and its switching in fluorescent organic nanoparticles. J. Am. Chem. Soc. 2002, 124, 14410-14415.

(38) Eisfeld, A.; Briggs, J. S. The J-band of organic dyes: lineshape and coherence length. Chem. Phys. 2002, 281, 61-70.

(39) Knapp, E. W. Lineshapes of molecular aggregates, exchange narrowing and intersite correlation. Chem. Phys. 1984, 85, 73-82.

(40) Das, S.; Bwambok, D.; El-Zahab, B.; Monk, J.; de Rooy, S. L.; Challa, S.; Li, M.; Hung, F. R.; Baker, G. A.; Warner, I. M. Nontemplated approach to tuning the spectral properties of cyaninebased fluorescent nanoGUMBOS. Langmuir 2010, 26, 12867-12876.
(41) Coppeta, J.; Rogers, C. Dual emission laser induced fluorescence for direct planar scalar behavior measurements. Exp. Fluids 1998, 25, 1-15.

(42) Hanson, G. T.; McAnaney, T. B.; Park, E. S.; Rendell, M. E. P.; Yarbrough, D. K.; Chu, S.; Xi, L.; Boxer, S. G.; Montrose, M. H.; Remington, S. J. Green fluorescent protein variants as ratiometric dual emission $\mathrm{pH}$ sensors. 1. Structural characterization and preliminary application. Biochemistry 2002, 41, 15477-15488.

(43) Würthner, F.; Kaiser, T. E.; Saha-Möller, C. R. J-Aggregates: From Serendipitous Discovery to Supramolecular Engineering of Functional Dye Materials. Angew. Chem., Int. Ed. 2011, 50, 33763410.

(44) Klonis, N.; Sawyer, W. H. Spectral properties of the prototropic forms of fluorescein in aqueous solution. J. Fluoresc. 1996, 6, 147157.

(45) Sjöback, R.; Nygren, J.; Kubista, M. Absorption and fluorescence properties of fluorescein. Spectrochim. Acta, Part A 1995, 51, L7-L21.

(46) Lan, M.; Zhang, J.; Chui, Y.-S.; Wang, P.; Chen, X.; Lee, C.-S.; Kwong, H.-L.; Zhang, W. Carbon nanoparticle-based ratiometric fluorescent sensor for detecting mercury ions in aqueous media and living cells. ACS Appl. Mater. Interfaces 2014, 6, 21270-21278.

(47) Yang, C. J.; Jockusch, S.; Vicens, M.; Turro, N. J.; Tan, W. Light-switching excimer probes for rapid protein monitoring in complex biological fluids. Proc. Natl. Acad. Sci. U.S.A. 2005, 102, 17278-17283.

(48) Min, Y.; Akbulut, M.; Kristiansen, K.; Golan, Y.; Israelachvili, J. The role of interparticle and external forces in nanoparticle assembly. Nat. Mater. 2008, 7, 527-538.

(49) Shaner, N. C.; Steinbach, P. A.; Tsien, R. Y. A guide to choosing fluorescent proteins. Nat. Methods 2005, 2, 905-909.

(50) Liu, Q.; Guo, B.; Rao, Z.; Zhang, B.; Gong, J. R. Strong twophoton-induced fluorescence from photostable, biocompatible nitrogen-doped graphene quantum dots for cellular and deep-tissue imaging. Nano Lett. 2013, 13, 2436-2441.

(51) Lu, C.; Das, S.; Magut, P. K. S.; Li, M.; El-Zahab, B.; Warner, I. $M$. Irradiation induced fluorescence enhancement in PEGylated cyanine-based NIR nano-and mesoscale GUMBOS. Langmuir 2012, $28,14415-14423$. 